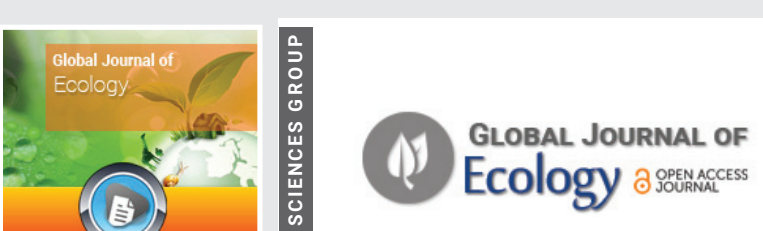

\section{The substitution of agrobased society for industrial society: A perspective of transforming societies}

\author{
Hongyun Han* and Sheng Xia \\ Professor, Department of Agricultural Economics, Zhejiang University, China
}

Received: 28 September, 2021

Accepted: 09 October, 2021

Published: 11 October, 2021

${ }^{*}$ Corresponding author: Hongyun Han, Professor, Department of Agricultural Economics, Zhejiang University, China, Tel: 860571 56337046;

E-mail: hongyunhan@zju.edu.cn

ORCID: https://orcid.org/0000-0003-2969-3907

Keywords: Agricultural community; Dynamic community; Inevitability; Feasibility; Sustainability

Copyright: (C) $2021 \mathrm{Han} \mathrm{H}$, et al. This is an openaccess article distributed under the terms of the Creative Commons Attribution License, which permits unrestricted use, distribution, and reproduction in any medium, provided the original author and source are credited.

https://www.peertechzpublications.com

\title{
Abstract
}

Since the Industrial Revolution, a new era has arisen as the Anthropocene, in which human actions have become the main driver of global ecological crises outside the stable environmental state of the Holocene. During the Holocene, environmental change occurred naturally and Earth's regulatory capacity maintained the conditions that enabled human development. By contrast, oil-dependent industrial society has exerted ecological crises. Agrobased society, in which almost all demands of human can be supported by agriculture, might be the ultimate solution industrial society facing ecological crises, in which there is a paradigm shift from the general and unlimited economic growth pursued by virtue of oil dependence to agrobased growth. The substitution of agrobased society for industrial society is an evolutionary result of Negation, it is a negation of materialized industrial society. The core feature of agriculture is to use organisms as production objects and rely on life processes to achieve production goals. The substitution of agrobased society for industrial society is the precondition for a sustainable carbon cycle, breaking through resource shortage, alleviating the environmental pressure of economic development. Meanwhile, it is feasible for the substitution of an agro-based society for an industrial society associated with the development of bio technologies and environmental awareness.

\section{Introduction}

Over the past four decades, huge amount of attention has been paid to the Nature, this is reflected by contentious treaty negotiations on climate change and biodiversity due to the worries over planetary ecological crises, such as overloaded carbon sinks and climate changes, vanishing species, degraded ecosystems, and insufficient natural resources [1]. Witnessed the reemergence of a broader socio-ecological movement, in 2008 academics and activists gathered in Paris declared "a paradigm shift from the general and unlimited pursuit of economic growth to a concept of "right-sizing" the global and [2]. As an ecological equivalent of Roosevelt's response to the Great Depression of the 1930s, the financial crisis in 2008 had facilitated critically thinking of global politics about the growth ethic itself. Formalized in 2008, the idea of degrowth aims to keep economic growth within ecological limits [3]. The 2008's Green New Deal, proposed by The New Economics Foundation, suggested that the creation of economic prosperity was not senselessly decoupled from environmental issues [4,5]. Meanwhile, production with only minor environmental impact seems technically and economically feasible in most cases [6]; under the umbrella of ecological modernization, technooptimists have further proposed a transition to renewable resources as complementary paths out of the crisis to minimize the environmental impact of growth by overlooking the possibility of climate change other problems of cost and implementation [7].

No matter the pro-growth-man or anti-growth-man [8], "we have lived with a deep-seated belief that life will get better, that one should hope for abundance, and work toward obtaining it [9]. Despite the previous work noted above, behind this obvious but difficult question remains unclear: what exactly is the alternative of economic growth in the future? Therefore, the objective of this paper aims to answer the question if and how a process of economic growth can materialize from within a new agrobased society. So far these sociological insights and ideas have been remarkably absent from the scientific 
discussion about the substitution of agrobased society for industrial society, it is a through abandonment of capitalism and the establishment of a new paradigm of growing economy. This paper consists of three parts. After a brief introduction, the inevitability of substitution of agro-based society for industrial society is given in section 1, which provides the theoretical backbone for the claims made in this article; section 2 outlines the feasibility of substitution of agrobased society for industrial society because it is unlikely that material use will be reduced if the economy grows within classical paradigm of capitalism, a shift of growth mode based on foundation of technical and society will ensure the feasibility of social transformation. Then it is followed by a brief conclusion.

\section{The inevitability of the substitution of agro-based so- ciety for industrial society}

Ecological crises resulted from a paradigm shift of agricultural holocene to industrial anthropocene: After a long period of long-term collection, fishing and hunting society, human beings began to breed plants, and thus entered the primitive agriculture stage. Beginning about 100000 years ago, a later but even more profound impact of humans on fauna was the domestication of animals [10], and this continued "into the Holocene with horses, sheep, cattle, goats, and the other familiar farm animals. The concomitant domestication of plants during the early to mid-Holocene led to agriculture" [11] "Agriculture appears to have originated at least 15,000 years ago, with the domestication of pigs in Mesopotamis, where rice was cultivated by humans in China as far back as 13,500 years ago; sorghum was domesticated in Africa 7,000 years ago, and maize was grown 6,000 years ago in Mesonamerica. Food surpluses were a result of farming domesticated species, and this empowered the development of human civilization" [12].

Although it is very short in the entire human history, development of agricultural society is a landmark in human history as human beings have evolved from food collectors to food producers with stable and continuous supply. Without agriculture, there would be no human civilization [13]. Without pressure from humans, the agricultural Holocene is expected to continue for at least several thousands of years [14]. in which prosperous human civilizations arise, develop and thrive.

It has proved that early agricultural development around the mid-Holocene fundamentally affected the functioning of the Earth System [15], the clearing of forests for agriculture about 8000 years ago and irrigation of rice about 5000 years ago led to increases in atmospheric carbon dioxide $\left(\mathrm{CO}_{2}\right)$ and methane $\left(\mathrm{CH}_{4}\right)$ concentrations [16]. It is undoubted that the human imprint on environment may have been discernible at local, regional, and even continental scales, but preindustrial humans did not have the technological or organizational capability to dominate the great forces of nature, the planet's environment has been unusually stable for the past 10,000 years [17].

It is believed that the advent of agriculture remains an intriguing but unproven beginning of the Anthropocene [11]. Since the Industrial Revolution, a new era has arisen as the Anthropocene [17], in which human actions have become the main driver of global environmental changes outside the stable environmental state of the Holocene. Proposed by Crutzen and Stoermer [18], the Anthropocene proposed that we are now living in a new geological epoch of the age of humans, which is believed to begin "at around $\mathrm{AD} 1800$ or the beginning of the Industrial revolution" [19].

It is a far-reaching economic transition from agricultural economy, characterized by low productivity and stagnant growth of agricultural economy, to industrial revolution with developed productivity and continuous growth. In the pursuit of wealth and prosperity, mankind's production modes have been fundamentally changed by machine production and factory systems. With the coordination of systems and rules, machinery application pushed by fossil fuels have released production capacity. This industrial capital paradigm of "Great Transformation" has swept the world like a whirlwind [20]. As the first industrial society, Britain was the richest and most powerful country in the world. During the century of the 19th century, the production of raw coal in Britain increased by 20 times, the production of pig iron increased by 30 times, and the import of raw cotton increased by 30 times [21].

Although both its scientific legitimacy and broader social meaning are still being discussed, the concept of the Anthropocene has attracted public and scholarly recognition in recent years [6]. Beyond academia, the Anthropocene is a popular concept and umbrella term for the understanding of environmental crises [22]. The entry of mankind into an industrial society is a great leap of human history. With the increase in productivity, a huge amount of wealth has been created; at the same time, earth-shaking changes have undergone in social politics, economies, cultures, and technologies. In the 250 years after the industrial revolution, the types of products produced and consumed increased from less than 1,000 to nearly 10 billion. According to the statistics in October 2017, there were 598 million products sold on Amazon. com alone [23].

The industrial society has created a miracle of economic growth by ignoring its impact on natural environment and resources. During the Holocene, environmental change occurred naturally and Earth's regulatory capacity maintained the conditions that enabled human development. In industrial society, largely because of a rapidly growing reliance on fossil fuels and industrialized agriculture, human activities have reached a level that could not keep Earth in the desirable Holocene state. The result could be irreversible and, in some cases, abrupt environmental change, leading to a state less conducive to human development [24]. In less than three centuries, the industrial society has achieved great success; at the same time, it is also facing severe crises, such as resource shortages, environment degradation, and unsustainable development.

A paradigm shift from degrowth to agrobased growth based on entropy theory

According to the second law of thermodynamics, a closed thermodynamic system is what exchanges no matter and no 
energy with its environment [25]. Therefore, "matter is subject to irrevocable dissipation just as available energy is continuously transformed into unavailable energy" (Smith and Smith, 1996 p.310). While the ability of the human species to transform the planetary environment has reached an unprecedented scale and magnitude in the past few decades (Jonsson, 2015), the development of industrial civilization has approached its limits [26]. In recent years, the world economy has been "fragile, unbalanced and trapped by risks" and is facing the threat of a new mediocre era (Rajad, 2014) that has maintained low growth for a long time. Even a world with zero population growth and a steady state economy at current consumption levels is not sustainable in perpetuity [25], because resource exhaustion in a finite period is inevitable because nonrenewable resources tend to irretrievably dissipate. This has pushed scholars to think about the Anthropocene age with supposed scarcity of ecological space [1].

One important concept is what Lakatos [27] has called a research programme of the paradigm of degrowth, which tries to expose the impossibility of exponential economic growth in a finite world and to outline alternative trajectories for social development as a rational cognition that the productive economy of industrial society is approaching the earth's carrying limit. Actually, it was during the mid- to late-1970s that the word Décroissance, the French word for degrowth, was first mentioned in the work of Nicholas Georgescu-Roegen, he proposed that even a world with zero population growth and a steady state economy at current consumption levels is not sustainable in perpetuity because nonrenewable resources tend to irretrievably dissipate [28]. Although degrowth has not been an activist slogan until after 2000 [29], the financial and economic turmoil recently on top of the ever-present environmental problems has invigorated doubts about the deep-seated anthropocenic idea that prosperity depends on economic growth. Before the fundamental adjustment of the growth paradigm, the degrowth trend seems inevitable [30], its ultimate aim of degrowth is the so-called 'steady state economy' [31].

The idea of degrowth sounds simple to halt or slow down economic growth in order to bring economies back within an ecological limit [17]. Due to the radical consequences of canceling out economic growth, degrowth raises questions about its practical feasibility [32]. The industrial economy has come to the "tech plateau" where the air is thin, and the global economy has entered and will continue to be in an era of "Great Stagnation". Where the society should go? Agrobased society is expected to substitute for industrial society. Since the Industrial Revolution, the consumption level of global resources, especially non-renewable mineral resources, has risen sharply. "Industrial societies as a rule use four or five times as much energy as did agrarian ones, which in turn used three or four times as much as did hunting and gathering societies" [11].

Schrodinger [33] have pointed out that a living organism does not need just energy but also low entropy, which it sucks from the environment and degrades into high entropy (waste).
This continuous flow of low entropy maintains the biological body in good order and also supports all activities of the organism. According to the Entropy Law, degradation of the resource base, the transformation of useful matter and energy into unavailable matter and energy is a unidirectional and irrevocable process. "Therefore, entropy may be seen as the ultimate physical basis of scarcity. The inability to reuse matter and energy in conjunction with finite sources of matter and energy implies the existence of a physical barrier to maintain an economic system in a stationary state" [34].

"Perhaps no other law occupies a position in science as singular as that of the Entropy Law. It is the only natural law which recognizes that even the material universe is subject to an irreversible qualitative change, to an evolutionary process" [28]. According to Arthur Eddington, the law that entropy always increases-the second law of thermodynamics-holds, which has played an important role in justification for the idea that economies have limits to growth [35]. If entropy is an index of the amount of available energy relative to the absolute temperature of the corresponding isolated system [36], all of these considerations are closely tied in with the concepts of order/ disorder, and of entropy. Surprisingly perhaps, even information content can be defined in terms of order/ disorder and therefore of entropy[37]. According to Clausius, an isolated system can exchange neither energy nor matter with its outside environment. In 1850, German physicist Rudolph Clausius discovered that it is impossible to transfer heat from a low-temperature object to a high-temperature object without causing other changes. If this direction is reversed, it needs to consume energy or cause other changes. This is the famous second law of thermodynamics. On the basis of this theory, Clausius created the word entropy. Entropy is a basic parameter that characterizes the state of matter, and its physical meaning is a measure of the degree of chaos in a system. Within closed systems, entropy should be maximized and disorder should reign [33]. When the entropy reaches its maximum value, the entire system reaches the most disorderly equilibrium. The energy of the universe is constant. Therefore, the entropy of the universe tends to a maximum [36].

"Closed systems exchange energy but no matter with their environment" [35]. For a closed system, its entropy must increase over time. If entropy is regarded as an index of the amount of unavailable energy in a given thermodynamic system at a given moment of its evolution, "the entropy of a closed system continuously increases toward a maximum", "life seems to evade the entropic degradation to which inert matter is subject [28]. "The origin of life should not be seen as an isolated event. Rather, it represents the emergence of yet another class of processes whose goal is the dissipation of thermodynamic gradients" [38]. Living systems are characterized to increase access to energy sources, and/or increase the efficiency of currently employed energy transformation processes [39]. Since entropy law is about energy, it can be extended to matter only by analogy, "negetropy can be imported as the earth imports energy from the sun [40]. In the spatially open systems, plants and forests are subject to two opposing gradients: the thermodynamic degradation gradient and the 
incoming solar radiation gradient. Solar radiation provides the energy necessary for these systems to oppose thermodynamic degradation. "Life is an emergent phenomena created by the constant influx of solar radiation which maintains living systems in a non-equilibrium state" [41].

Agricultural production is a process of entropy reduction. "Some organisms slow down the entropic degradation. Green plants store part of the solar radiation", "all other organisms, on the contrary, speed up the march of entropy. Man occupies the highest position on this scale, and this is all that environmental issues are about" [28]. In 1943, Schrödinger said in a speech, "all things in nature tend to change from order to disorder, that is, entropy increases. Life needs to constantly offset the positive entropy generated in its life to maintain itself at a stable and low level of entropy. Life is based on negative entropy." In the following year, Schrödinger elaborated his theory in "What is Life", which played a leading role in the development of modern biology marked by DNA. Scientists generally believe that life phenomena are highly ordered, and life reduces its internal entropy. Prigogine [42] regards life form as a "dissipative structure", an open system far from equilibrium, which can exchange matter and energy with the outside world, thereby making it possible to realize the original disorder to order. The process of state evolution can maintain this process by dissipating matter and energy.

Without life, the earth will still fall into an endless loop of entropy increase. Humans move more earth and produce more reactive nitrogen than all other terrestrial processes combined [43]. "The crux of the argument revolves around the treatment of material resources. This is because the entropy law as a physical principle applies only in a closed system and then only to energy. However, since the earth is an open system with respect to energy any inevitable entropic decay or dissipation in the earth which sets a long-run physical limit on economic activity must occur for matter, not for energy" [40]. On the earth as an open system, agricultural activities can "exchange both energy and matter with the environment" [35]. Agriculture plays an important role from the perspective of entropy reduction.

New paradigms provide either a new, but constrained, reality, or an improved view of the old reality [41]. Agrobased society is a breakthrough in the inability of industrial society to sustain its own contradictions. Instead of mechanical forces to complete production tasks, agro-based production methods have four main characteristics: one is to use biological processes as much as possible; the second is to make full use of bio-energy instead of fossil energy; the third is to replace various minerals with biological materials; the fourth is the production process, that is, the metabolic process. Waste can be decomposed in the second metabolism, which is an environmentally friendly production method. Therefore, the substitution of agro-based society for industrial society provides a profound basis for the sustainable development of human economic society. The production of agro-based society is mainly realized through the life process. As the life process cycles, these substances eventually have realized the cycle.
Therefore, as long as the environment where life is located has not undergone major catastrophes, production will be sustainable by virtue of entropy reduction.

\section{The feasibility of substitution of an agro-based society for an industrial society}

Technological advancements providing basis for the substitution of agro-based society for industrial society: "Over the past several decades' rapid advances in transport, energy, agriculture, and other sectors have led to a trend of dematerialization in several advanced economies. The amount and value of economic activity continue to grow but the amount of physical material flowing through the economy does not" [11]. The significance of the Entropy Law in understanding the economic process has long been maintained by GeorgescuRoegen $[22,45]$. Economics processes are non-reversible. The economic process with biological systems that are entropyreducing and together with their environment contribute to the inevitable rise in the entropy of the universe [46]. The entropy argument was fundamentally flawed, and the limits to growth has not gone without challenge [34]. "Sooner or later, the productivity of oil will rise out of sight, because the production and consumption of oil will eventually dwindle toward zero, but real GNP will not"( [7]. There are further technological opportunities because worldwide energy use is equivalent to only $005 \%$ of the solar radiation reaching the continents [47], which plays an important role in reducing the pressure on the Earth System. Economic systems are highly evolved ecosystems that have harnessed a new substrate - knowledge - that enables them to extend their organized complexity and, correspondingly, their dissipative potential $[48,49]$. In addition to the many opportunities for energy conservation, numerous technologies are available now or under development to replace fossil fuels [50]. Although all thermodynamic laws, unlike most other natural laws, express an impossibility [36], the technosphere could supersede the biosphere in the future [9].

Proponents of the entropy law as a physical constraint on economic growth must show that it applies to matter as well as energy. The advancement of science and technology has made the production methods and final products of modern agriculture greatly different from those of traditional agriculture. Since the 1950s, the scientific community has gradually deepened the research on cells and the genes that control the genetic characteristics of cells. Gene recombination and cell fusion technologies can more effectively allow organisms to produce substances needed by humans, thereby agricultural products. New varieties and new technologies continue to emerge, different new technologies are promoting the progress of agriculture, especially life sciences and biotechnology. Bill Gates thought as early as 1996 that "biotechnology will change the world like computer software." With the help of biotechnology, farmers in the future will produce most of the items and raw materials needed by mankind in the field, such as rice, vegetables, fruits, meat, and even fuels, medicines, building materials, sensors, chips, etc.. The rapid development of biotechnologies in recent years has attracted widespread attention from the whole society and 
at the same time provides more possibilities for agriculture. According to scholars' statistics, there were 40 Nobel Prizes in Chemistry related to life sciences in 1901-2001, accounting for more than $1 / 3$ [51]. There were 8 Nobel Prizes in Chemistry from 2002 to 2016 related to life sciences, accounting for more than 1/2. 2018 was the year of biotechnology, and 8 scientists were awarded three natural science prizes, 4 of which were Related to the development of biotechnology. The new crown epidemic in 2020 has further provided a catalyst for the development of biotechnology. More and more people believe that the 21st century is the century of biotechnology, and the achievements of biotechnology are changing the state of agriculture and promoting social progress.

As a science of artifacts, "the capacity to produce has been augmented by the capacity for information transfer" [9]. At present, all countries attach great importance to the development of biotechnologies, and some developed countries and emerging economies have issued corresponding policies. In 2012, the United States released the "National Bioeconomy Blueprint for the United States Supporting the Bioeconomy". The European Union listed in "Innovation to Achieve Sustainable Growth: Bioeconomy in Europe", including genetically modified crops, forestry, fisheries, biopharmaceuticals, and new Molecular entities, biomarkers and genetic testing, as well as key areas such as biofuels, biochemicals, industrial enzymes for raw material production, biosensors, bioremediation, resource extraction and biorefining; in 2014, the OECD determined the structure of the biological industry The three main subindustries of the country are biomedicine, bioagriculture and bioindustry [52].

\section{Environmental awareness providing social basis for the substitution of agro-based society for industrial society}

Postmaterialist-value change is inadequate for explaining global environmentalism [53,54]. Although improved technology is essential for mitigating global change, it may not be enough on its own, changes in societal values and individual behavior will likely be necessary [55]. "Technology changes the future, but so do ideas. Ideas drive technology, and also drive the values that we choose to carry from past through the present, conserving or reforming them for the future. We are at a hinge point in our history, reevaluating how we value nature and human nature" [9]. "Whether we accept it or not, human beings now shoulder the responsibility of planetary management; once the planet was larger than us, but it no longer is [56]. Celebrated in a Ecomodernist Manifesto, a dozen and a half international environmental leaders have advocated "an ecologically vibrant planet" [57]. Surely this modern humanism will treasure ecosystem services. But these ecomodernists anticipate what they call decoupling. By this account, we need to be increasingly high tech to save nature [58].

Rockström [26] argues that there are nine planetary systems on which humans have exerted profound impacts. These can be seen by analysis of chemical pollution, climate change, ocean acidification, stratospheric ozone depletion, biogeochemical nitrogen-phosphorus cycles, global freshwater use, changing land use, biodiversity loss, atmospheric aerosol loading Since the Industrial Revolution, in three of these systems the boundaries have already been exceeded: biodiversity loss climate change, and the nitrogen cycle $[9,17]$. By examining the "rational man" and "value-neutral measurement" theories of neoclassical economics from different perspectives, scholars have a new understanding of the anthropocentrism tendency and the paranoia of rational measurement, and they believe that the analysis of "cost-benefit" The curve should be given new variables in the development of economics in the future (Bryant J., 2008). The overall environmental factor cannot be ignored in the economic decision-making of human beings to maximize the benefits. To pursue a better and quality life, environmental ethics is promoted by a large numbers of persons. The concept of ecological civilization has been developed by Ye in 1987 for the first time. From the perspective of ecological philosophy, he pointed out that ecological civilization means that mankind benefits both nature and man. It protects nature while transforming nature and maintains a harmonious and unified relationship between man and nature [59]. With the frequent occurrence of environmental problems in the later stages of industrial society, the ecological awareness of the whole society has been significantly improved. "Ecological modernization theory posits that advanced industrial nations can foster environmental improvements and economic sustainability through adjustments in production and consumption habits" [60]. "What we call 'saving the Earth' will, in practice, require creating and re-creating it again and again for as long as humans inhabit it" [61-66].

\section{Brief conclusion}

As humans has entered into Anthropocene, the negative impact of humans on environment is unprecedented. Sustainable development has been proved the only way of human society without feasible paths. Agrobased society, in which almost all demands of human can be supported by agriculture, will be an inevitable, necessary and feasible option of the society after industrial society. Abrobased society is a through abandonment of capitalism with a shift of growth paradigm based on development of biotechnologies; and more importantly, social environmental awareness will ensure the feasibility of social transformation. The substitution of agrobased society for industrial society is an evolutionary result of Negation of Negation, it is a negation of materialized industrial society. Meanwhile, the substitution of agrobased society for industrial society is the inherent requirements for a sustainable carbon cycle, a feasible alternative mode for breaking through the resource shortage of social development, the inherent requirements for alleviating the environmental pressure of social development. Meanwhile, the substation is a feasible option because the society has established the technological basis and social foundation for an agriculturalbased society to replace an industrial society.

\section{Funding}

This work was supported by the National Natural Science Foundation of China [grant number 72073119]. 


\section{References}

1. McAfee K (2016) The Politics of Nature in the Anthropocene. RCC Perspectives 2, Whose Anthropocene? Revisiting Dipesh Chakrabarty's "Four Theses" 6572. Link: https://bit.ly/2YAgJSG

2. Research and Degrowth (2008) Degrowth Declaration of the Paris 2008 conference. Journal of Cleaner Production 18: 523-524. Link: https://bit.ly/3BwyFfw

3. Boonstra WJ, Joosse S (2013) The Social Dynamics of Degrowth. Environmental Values 22: 171-189. Link: https://bit.ly/30gpXEn

4. Mauerhofer $V$ (2019) Legal institutions and ecological economics: their common contribution for achieving a sustainable development. Ecol Econ 156: 350-335. Link: https://bit.ly/3AyhGrl

5. Spash CL (2012) Towards the integration of social, economic and ecological knowledge. SRE-Discussion Papers 2012/04, WU Vienna University of Economics and Business. Link: https://bit.ly/3ltP3b5

6. Martinez-Alier J, Naredo JM (1982) A Marxist Precursor of Energy Economics: Podolinsky. Journal of Peasant Studies 207-224. Link: https://bit.ly/3uZsUo4

7. Jonsson FA ( 2015) Anthropocene Blues: Abundance, Energy, Limits, RCC Perspectives, No. 2, The Imagination of Limits: Exploring Scarcity and Abundance 55-64. Link: https://bit.ly/3mDJWV7

8. Solow RM (1973) Is the End of the World at Hand? Challenge 16: 39-50. Link: https://bit.ly/3iPHIpL

9. Rolston III H (2017) Technology and/or Nature: Denatured/Renatured/ Engineered/Artifacted Life? Ethics and the Environment 22: 41-62. Link: https://bit.ly/3mMLts6

10. Leach HM (2003) Human domestication reconsidered. Curr Anthropol 44 349-368. Link: https://bit.ly/3AoWDYE

11. Steffen W, Crutzen PJ, McNeill JR (2007) The Anthropocene: Are Humans Now Overwhelming the Great Forces of Nature? Ambio: J Human Environment 36: 614-621. Link: https://bit.ly/3uZt7aQ

12. Rhodes CJ (2017) The imperative for regenerative agriculture. Sci Prog 100 80-129. Link: https://bit.ly/3oQmhDC

13. Claessen HJM, Skalnik P (1978) The Early State.Hague:Mouton Publisher. Link: https://bit.ly/3ltb8GE

14. Berger A, Loutre MF (2002) An exceptionally long interglacial ahead? Science 297: 1287-1288. Link: https://bit.ly/3iRC1IM

15. Ruddiman WF (2003) The anthropogenic greenhouse era began thousands of years ago. Climat Chang 61: 261-293. Link: https://bit.ly/3mFLu0T

16. Lambin EF. Geist HJ (2006) Land-Use and Land-Cover Change. Local Processes and Global Impacts The IGBP Global Change Series, SpringerVerlag, Berlin, Heidelberg, New York, 222. Link: https://bit.ly/3lt|KUV

17. Rockström J, Steffen W, Noone K, Persson Å (2009) Planetary Boundaries: Exploring the Safe Operating Space for Humanity. Ecology and Society 14: 32 Link: https://bit.ly/3o07Uzs

18. Crutzen PJ, Stoermer EF (2000) The 'Anthropocene.' Global Change Newsletter 41: 17-18. Link: https://bit.ly/3uYiUeG

19. Knight KW, Mess BL (2012) Environmental Concern in Cross-National Perspective: The Effects of Affluence, Environmental Degradation, and World Society. Social Science Quarterly 93: 521-537. Link: https://bit.ly/3mKGiJ5

20. Polanyi K (1957) The Great Transformation. Boston: Beacon Press 6. Link: https://bit.ly/3iP14pO

21. Briggs A (1987) A Social History of England. London 217-218.
22. Thornton TF, Thornton PM (2015) The Mutable, the Mythical, and the Managerial: Raven Narratives and the Anthropocene. Environment and Society 6: 66-86. Link: https://bit.ly/3BvHaHH

23. Zhang WY (2018) The three industrial revolutions I have experienced. Small and Medium-sized Enterprises in China 2018: 59-63.

24. Steffen W, Grinevald J, Crutzen P, McNeill J (2011) The Anthropocene: conceptual and historical perspectives. Philosophical Transactions Royal Society A: Mathematical, Physical and Engineering Sciences 369: 842-867. Link: https://bit.ly/3iPkKtB

25. Georgescu-Roegen N (1976) The entropy law and the economic problem. In Energy and economic myths: Institutional and analytical essays. New York: Pergamon Press 53-60

26. Rockström J, Steffen W, Noone K, Persson Å, Chapin FS, et al. (2009) A Safe Operating Space for Humanity. Nature 461: 472-475. Link: https://go.nature.com/3v01U7P

27. Lakatos I (1970) History of science and its rational reconstructions. PAS proceedings of the biennial meeting of philosophy of science association 91 136. Link: https://bit.ly/3AzxIXH

28. Georgescu-Roegen N (1975) Energy and Economic Myths. Southern Economic Journal 41: 347-381. Link: https://bit.ly/3oTXE8X

29. Whitehead M (2013) Degrowth or Regrowth? Environmental Values 22: 141 145. Link: https://bit.ly/3AoWILW

30. Garcia E (2012) Degrowth, the Past, the Future, and the Human Nature. Futures 44: 546-552. Link: https://bit.ly/30eD9cV

31. Daly HE (1991) Steady-state economics. Washington, D.C.: Island Press. Link: https://bit.ly/3AvHtRw

32. Foster JB, Magdoff $F$ (2010) What every environmentalist needs to know about capitalism. Monthly review 61: 1-30. Link: https://bit.ly/3mDKdr7

33. Schrödinger E (1944) What is Life? Cambridge University Press. Link: https://bit.ly/3Bx91qP

34. Young JT (1983) Entropy, Scarcity, and Neo-Ricardianism. Journal of Post Keynesian Economics. 6: 82-88. Link: https://bit.ly/3arSM2A

35. Smith CE, Smith JW (1996) Economics, Ecology and Entropy: The Second Law of Thermodynamics and the Limits to Growth. Population and Environment 17: 309-321. Link: https://bit.ly/3oN7JEz

36. Georgescu-Roegen N (1986) The Entropy Law and the Economic Process in Retrospect, Eastern Economic Journal 12: 3-25. Link: https://bit.ly/3DrTCbY

37. Lovejoy D (1996) Limits to Growth? Science \& Society Fall 60: 266-278.

38. Schneider E, Kay J (1994) Life as a manifestation of the second law of thermodynamics. Math Comput Model 19: 25-48. Link: https://bit.ly/3AxIWYB

39. Buensdorf G (2000) Self-organization and sustainability: energetic of evolution and the implications for ecological economics. Ecol Econ 33: 119-134. Link: https://bit.ly/3v1vKsw

40. Young JT (1991) Is the entropy law relevant to the economics of natura resource scarcity? Journal of Environmental Economics and Management 21 169-179. Link: https://bit.ly/3ltbkFS

41. Raine A, Foster J, Potts $J$ (2006) The new entropy law and the economic process. Ecological Complexity 3: 354-360. Link: https://bit.ly/3mMLMmK

42. Prigogine I (1969) Structure, Dissipation and Life. Theoretical Physics and Biology, Versailles, 1967. North-Holland Publ. Company, Amsterdam. Link: https://bit.ly/3oRAEHI 
43. Galloway JN (2004) The Global Nitrogen Cycle. in Biogeochemistry, edited by W.H. Schlesinger, in Treatise on Geochemistry, edited by H.D. Holland and K.K. Turekain. Oxford, UK: Elsevier-Pergamon 8.

44. Kuhn TS (1962) 1970 by The Structure of Scientific Revolutions. 1st and 2d ed enl. Chicago: University of Chicago Press. Link: https://bit.ly/3oPAccV

45. Georgescu-Roegen N (1971) The Entropy Law and the Economic Process. Harvard University Press, Cambridge. Link: https://bit.ly/2YzJZtb

46. English JM (1975) A Review of The Entropy Law and the Economic Process. By Nicholas Georgescu-Roegen. Harvard University Press, 1971. The Engineering Economist 20: 226-227. Link: https://bit.ly/3mMLNHk

47. Haberl H, Weisz H, Amann C, Bondeau A, Eisenmenger N, et al. (2006) The energetic metabolism of the European Union and the United States, decadal energy inputs with an emphasis on biomass. J Ind Ecol 10: 151-171. Link: https://bit.ly/3iKsT2v

48. Miller G (1999) Waste is good. Prospect 2: 18-23. Link: https://bit.ly/2YzcN4r

49. Potts J (2003) Toward an evolutionary theory of homoeconomicus: the concept of universal nomadism. In: Georgescu-Roegen N. (1971) The Entropy Law and the Economic Process. Harvard University Press, Harvard.

50. Rahmstorf S, Cazenave A, Church JA, Hansen JE, Keeling RF, et al. (2007) Recent climate observations compared to projections. Science 316: 709. Link: https://go.nasa.gov/3DomlOI

51. Ren YG, Li XH, Song YQ (2012) The contribution of chemistry and physical technology to the development of life sciences viewed from the Nobel Prize. Bulletin of Biology 47: 59-62

52. Bai JY, Lin XF, Ding JQ (2020) The development status of my country's biological industry and policy recommendations. Bulletin of the Chinese Academy of Science 35: 1053-1060.

53. Brechin SR, Kempton W (1994) Global Environmentalism: A Challenge to the Postmaterialism Thesis? Social Science Quarterly. Link: https://bit.ly/2YyRdwY

54. Dunlap RE, Mertig AG (1997) Global Environmental Concern: An Anomaly for Postmaterialism. Social Science Quarterly 78: 24-29. Link: https://bit.ly/3DuDCWQ
55. Fischer J, Manning AD, Steffen W, Rose DB, Daniell K, et al. (2007) Mind the sustainabihty gap. Trends Ecol Evol in press 22: 621-624. Link: https://bit.ly/3aqkNaF

56. Thompson A (2009) Responsibility for the End of Nature or, How I Learned to Stop Worrying and Love Global Warming. Ethics and the Environment 14 79-99. Link: https://bit.ly/3DrTHMO

57. John AA, Blomqvist L, Brand S, Brook B, DeFries R, et al. (2015) An Ecomodernist Manifesto. Link: https://bit.ly/3FxCx25

58. Steffen W, Broadgate W, Deutsch L, Gaffney O, Ludwig C, et al. (2015) The Trajectory of the Anthropocene: The Great Acceleration. Anthropocene Review 2: 81-89. Link: https://bit.ly/3AuF4q4

59. Qianji Y (1987) The era of real civilization has just begun-Professor Ye Qianj called for "ecological civilization construction". China Environment News.

60. Walker BL (2007) Ecological Modernization and Japan by Brendan F. D. Barrett Review by Brett L. Walker. The Journal of Japanese Studies 33: 294-298. Link: https://bit.ly/3Bxgk1V

61. Shellenberger M, Nordhaus T (2011) Evolve: A Case for Modernization as the Road to Salvation. Orion 30: 60-65.

62. Diamond J (2016) Guns, germs and steel: the fate of human society. Xie Yanguang, Trans. Shanghai: Shanghai Translation Publishing House. Link: Link: https://bit.ly/3iR7sg5

63. Han HY, Xia Sh (2018) On the deepening of China's agricultural capital. Hangzhou: Zhejiang University Press.

64. John AA, Blomqvist L, Brand S, Brook B, DeFries R, et al. (2015) An Ecomodernist Manifesto. Link: https://bit.ly/3FxCx25

65. Kant (1980) Critique of Pure Reason. Beijing: The Commercial Press

66. Machida T, Nakazawa T, Fujn Y, Aoki S, Watanabe O (1995) Increase in the atmospheric nitrous oxide concentration during the last 250 years. Geophys Res Lett 22: 2921-2924. Link: https://bit.ly/3AB3pe8

\section{Discover a bigger Impact and Visibility of your article publication with}

\section{Peertechz Publications}

\section{Highlights}

* Signatory publisher of ORCID

* Signatory Publisher of DORA (San Francisco Declaration on Research Assessment)

* Articles archived in worlds' renowned service providers such as Portico, CNKI, AGRIS, TDNet, Base (Bielefeld University Library), CrossRef, Scilit, J-Gate etc.

* Journals indexed in ICMJE, SHERPA/ROMEO, Google Scholar etc.

* OAI-PMH (Open Archives Initiative Protocol for Metadata Harvesting)

* Dedicated Editorial Board for every journa

* Accurate and rapid peer-review process

* Increased citations of published articles through promotions

* Reduced timeline for article publication

Submit your articles and experience a new surge in publication services (https://www.peertechz.com/submission).

Peertechz journals wishes everlasting success in your every endeavours. 